\title{
PENGOLAHAN LIMBAH CAIR INDUSTRI PERCETAKAN UANG KERTAS (UTAS) MENGGUNAKAN PROSES BIOLOGIS ANAEROB
}

\author{
Oleh : \\ Rudi Nugroho*, Ikbal *dan Nurtya Sulasmi** \\ *Peneliti di Pusat Teknologi Lingkungan - BPPT \\ ${ }^{* *}$ Mahasiswi Jurusan Bioteknologi - Institut Teknologi Indonesia
}

\begin{abstract}
A research of wastewater treatment technology come from money producing industry was conducted in laboratory scale using 10 It of Anaerobic Fixed Bed Reactor. The money producing wastewater was treated by mixing with domestic wastewater with various compositions. The wastewater was fed into the bioreactor by draw and fill daily. The results show that the optimum of COD removal is $52,5 \%$, optimum loading is 0 , $95 \mathrm{~g}-\mathrm{COD} / \mathrm{l} / \mathrm{day}$ and optimum flowrate is $0,5 \mathrm{l} /$ day. The optimum compossition of money producing wastewater towards domestic wastewater is 30\%. These optimum conditions can be used as a designed criteria for full scale of anaerobic bioreactor in the money producing industry.
\end{abstract}

\section{Katakunci : Wastewater, Anaerobic, Fixed Bed Reactor}

\section{PENDAHULUAN}

Menurut Mahida (1984), limbah cair adalah sampah cair dari suatu lingkungan masyarakat yang komponen terbesarnya terdiri dari air yang telah digunakan dan kira-kira $0,1 \%$ terdiri dari benda-benda padat organik dan anorganik. Limbah cair juga menjadi tempat perkembangbiakan jasad renik seperti bakteri, virus, dan protozoa.

Limbah cair memberikan ciri yang dapat diidentifikasi secara visual dan secara pengujian di laboratorium. Identifikasi limbah cair secara visual dapat diketahui dari kekeruhan, warna limbah, rasa, dan bau yang ditimbulkan, tetapi kandungan senyawa kimia limbah cair harus diidentifikasi secara laboratorium untuk memastikannya. Pada umumnya di dalam limbah cair sering ditemukan padatan terlarut, padatan tidak larut, mikroorganisme, dan senyawa kimia organik (Gintings, 1992). Menurut sumbernya dapat dibedakan menjadi limbah cair domestik dan limbah cair industri (Rudi Nugroho, 2006).

Limbah cair domestic merupakan limbah yang dikeluarkan dari aktifitas manusia seperti mandi, cuci, kantin mushola dan lain sebagainya. Kandungan pencemar terbesar dari limbah cair ini adalah senyawa organik. dimana kuantitasnya antara $(60-80) \%$ dari rata-rata pemakaian air bersih (Rudi Nugroho, 2006). Sesuai dengan sumbernya, maka limbah cair domestik mempunyai komposisi yang sangat bervariasi dari setiap tempat dan setiap saat. Secara garis besar karakteristik limbah cair domestik dapat dilihat pada Tabel 1 (Metcalf and Eddy, 1991).

Limbah cair ndustri merupakan limbah cair yang dikeluarkan dari proses produksi di suatu industri.
Komposisi dari limbah cair ini sangat bervariasi tergantung dari jenis industri.

Secara umum kualitas limbah cair industri berbeda dengan limbah cair domestik. Kandungan organik dalam limbah cair domestik sebagian besar bersifat biodegradable artinya bisa diurai secara biologis. Sedangkan limbah cair industri belum tentu, kecuali industri-industri pemroses hasil pertanian dan industri peternakan. Limbah cair domestik maupun industri apabila tidak diolah dengan benar akan berdampak terhadap pencemaran lingkungan. Salah satu industri yang mengeluarkan limbah cair dengan kandungan polutan dengan konsentrasi yang sangat tinggi adalah adalah limbah cair dari Industri Percetakan Uang.

Di Indonesia, Industri percetakan uang adalah PT. $X$ yang berlokasi Daerah Kerawang Jawa Barat. Limbah cair yang dihasilkan berasal dari proses produksi uang kertas (utas) dan kegiatan domestik. Limbah dari proses utas merupakan bahan-bahan yang banyak mengandung tinta, minyak dan bahan kimia lainnya dengan karakteristik $C O D$ dan $B O D$ sangat tinggi. Selain limbah cair utas, dengan banyaknya karyawan, maka limbah cair domestik seperti dari kantin, toilet karyawan, kamar mandi dan wastafel yang dihasilkan juga banyak, dan kedua jenis limbah ini sangat berpotensi sekali menimbulkan pencemaran lingkungan perairan sekitar apabila tidak dilakukan pengolahan dengan benar.

Dalam proses pembuatan uang kertas, menggunakan mesin cetak yang dinamakan mesin cetak intaglio. Mesin ini secara periodik dilakukan pembilasan sisa-sisa tinta yang menempel di permukaan cetakan menggunakan 
larutan. Larutan yang digunakan untuk membilas terdiri dari campuran minyak jarak, sodium hidroksida dan air. Larutan ini dinamakan "wipping sollution". Di Industri percetakan uang PT. $X$, proses pencucian berlangsung secara tertutup. Artinya larutan yang telah dipakai untuk mencuci diproses dan kemudian dipakai kembali. Namun setelah periode 3 bulan, larutan ini sudah tidak layak lagi sehingga harus diganti dengan larutan yang baru, sehingga menghasilkan limbah cair utas yang harus diolah.

Dari hasil survei lapangan dan diskusi dengan pihak industri, Industri percetakan uang ini menghasilkan limbah cair utas yang memiliki konsentrasi COD sekitar $60.000-80.000 \mathrm{mg} / \mathrm{l}$ dengan jumlah sekitar $150 \mathrm{~m}^{3}$ per 3 bulan, sedangkan untuk limbah cair domestiknya sekitar $120 \mathrm{~m}^{3} /$ hari. Kedua limbah cair ini belum dilakukan pengelolaan dengan baik sehingga limbah cair yang dibuang ke lingkungan masih berada di atas baku mutu yang ditetapkan pemerintah yaitu Keputusan Menteri Lingkungan Hidup Nomor KEP-51/MENLH/10/1995.

Dalam makalah ini diulas mengenai hasil penelitian pengolahan limbah cair industri percetakan uang secara terpadu untuk limbah produksi utas dan kegiatan domestik. Penelitian yang dilakukan adalah dengan menggunakan teknologi proses biologis anaerob skala laboratorium. Alat yang digunakan berupa bioreaktor Anaerob tipe unggun tetap (Anaerobic Fixed Bed Reactor). Umpan reaktor (influen) terdiri dari campuran limbah cair utas dalam limbah cair domestik dengan perbandingan tertentu.

\section{TUJUAN}

Penelitian ini bermaksud untuk mengkaji kinerja Anaerobic Fixed Bed Reactor untuk menurunkan polutan dalam limbah cair utas, ditinjau dari faktor konsentrasi limbah cair utas dalam limbah cair domestik dan faktor jumlah influen. Sedang tujuan penelitian ini adalah untuk mengetahui kemampuan maksimal dari Anaerobic Fixed Bed Reactor dalam mendegradasi limbah cair utas dengan 3 parameter yang diamati yaitu nilai $\mathrm{COD}, \mathrm{pH}$, dan warna pada variasi konsentrasi limbah cair utas dan variasi jumlah influen. Pada akhirnya diharapkan akan diperoleh konsentrasi limbah cair utas, jumlah influen dan beban COD yang optimal. Selanjutnya kondisi yang optimal ini dapat digunakan untuk menentukan besarnya instalasi pengolahan limbah cair industri percetakan uang.

\section{METODE PENELITIAN}

\subsection{Bahan}

Limbah cair yang menjadi obyek penelitian ini adalah limbah cair utas yang merupakan cairan yang berasal dari pencucian mesin pencetak uang (Intaglio Printing), yang terdapat pada industri percetakan uang PT. X. Sedangkan mikroba yang digunakan dalam penelitian adalah mikroba anaerob yang diambil dari bioreaktor anaerob Instalasi Pengolahan Air Limbah Rumah Potong Hewan (IPAI RPH) Cakung. Dalam bioreaktor penelitian, mikroba ini tumbuh dan melekat pada media penyangga (support material) dengan tipe bioball yang terbuat dari plastik polietilen, berdiameter $4 \mathrm{~cm}$, porositas $91 \%$, berat jenis $0,97 \mathrm{~kg} / \mathrm{m}^{3}$, luas permukaan 230 $\mathrm{m}^{2} / \mathrm{m}^{3}$ dan berwarna hitam. Media penyangga bioball tersebut dapat dilihat pada Gambar 1.

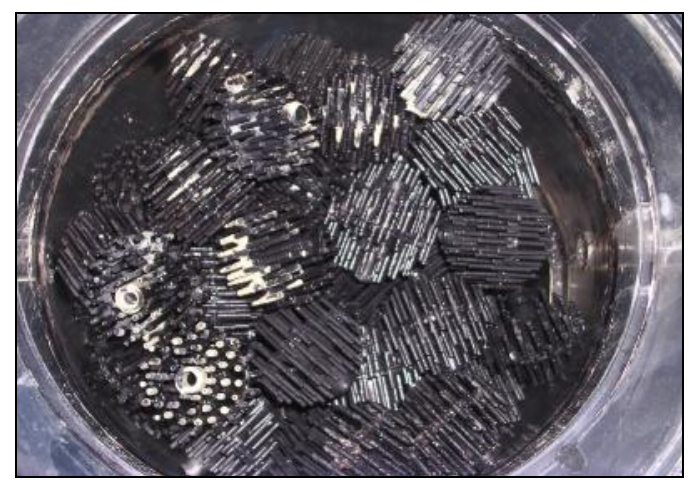

Gambar 1. Media Penyangga Bioball

Bahan kimia yang digunakan dalam penelitian adalah Bahan-bahan kimia penunjang untuk analisa meliputi akuades sebagai pelarut, larutan $\mathrm{K}_{2} \mathrm{Cr}_{2} \mathrm{O}_{7} \quad 0,25 \mathrm{~N}$ sebagai reagen untuk analisa $\mathrm{COD}, \mathrm{H}_{2} \mathrm{SO}_{4}$ pekat sebagai bahan untuk pembuat reagen $\mathrm{COD}, \mathrm{Ag}_{2} \mathrm{SO}_{4}$ sebagai bahan pencampur dengan $\mathrm{H}_{2} \mathrm{SO}_{4}$ untuk pembuatan reagen yang digunakan untuk analisa COD, buffer 4 dan 7 sebagai bahan standarisasi untuk analisa $\mathrm{pH}, \mathrm{HCl}$ dan kertas lakmus.

\subsection{Peralatan}

\subsubsection{Peralatan Analisa}

Peralatan utama analisa yang digunakan adalah HORIBA pH meter F-22, spektrofotometer Hach DR 2000, COD Reaktor Hach dan KOKUSAN Sentrifuge H-103 N series. Peralatan analisa penunjang adalah labu erlenmeyer, labu ukur $50 \mathrm{ml}$ dan $100 \mathrm{ml}$, beaker glass, pipet ukur, propipet, botol COD, COD reaktor, ember, gayung, siring glass $100 \mathrm{ml}$, oven bersuhu $105^{\circ} \mathrm{C}$, desikator, serta alat pemanas. 


\subsubsection{Peralatan Penelitian}

Bioreaktor anaerob yang digunakan untuk mengolah limbah cair utas adalah tangki berbentuk silinder yang terbuat dari bahan akrilik dengan dimensi tinggi $48 \mathrm{~cm}$, diameter $20 \mathrm{~cm}$ dan volume operasi 12 I. Pengadukan isi bioreaktor dilakukan dengan sirkulasi cairan di dalam bioreaktor dengan bantuan pompa sirkulasi jenis Iwaki Matering Pump dengan tipe Ex-B30VH-100S dengan kapasitas $100 \mathrm{ml} / \mathrm{menit}$ yang beroperasi 24 jam. Sirkulasi ini diperlukan untuk membebaskan biogas yang terbentuk serta menjaga homogenitas isi bioreaktor. Gambar 2 dan 3 adalah skema dan rangkaian peralatan yang digunakan untuk penelitian limbah cair Industri Percetakan Uang dengan proses pengolahan biologis anaerob.

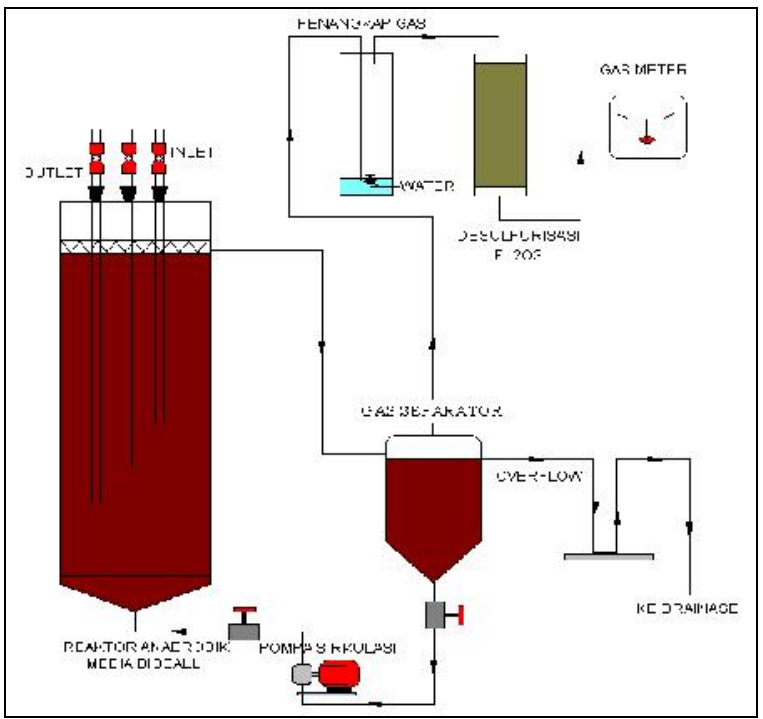

Gambar 2. Skema Peralatan Penelitian Pengolahan Limbah Cair Percetakan Uang

Cara kerja bioreaktor anaerob ini diawali dengan memasukkan influen limbah cair ke dalam bioreaktor yang sudah berisi bioball dan mikroorganisme anaerob, lalu limbah tersebut dialirkan ke gas separator dengan bantuan pompa melalui weir dengan tujuan agar aliran limbah pelan-pelan atau laminar. Kemudian dari gas separator dialirkan kembali ke dalam bioreaktor dengan bantuan pompa pula.

Proses anaerob akan menghasilkan gas metan. Gas metan ini akan dibebaskan dalam gas separator selanjutnya akan mengalir ke pipa penangkap gas lalu ke bak desulfurisasi yang didalamnya berisi $\mathrm{Fe}_{2} \mathrm{O}_{3} . \mathrm{Fe}_{2} \mathrm{O}_{3}$ berfungsi sebagai pengabsorbsi senyawa $\mathrm{H}_{2} \mathrm{~S}$ yang dihasilkan dari penguraian senyawa-senyawa sulfat dan merupakan senyawa racun bagi mikroorganisme serta bersifat korosif.

Pada gas separator terdapat dua pipa, yaitu pipa pertama yang menghubungkan dengan bioreaktor anaerob dan pipa kedua untuk mengalirkan kelebihan cairan pada saat memasukkan influen. Pipa kedua ini berbentuk "U" yang di dalamnya terdapat air yang berfungsi agar udara dari luar tidak masuk sehingga kondisi di dalam bioreaktor akan tetap anaerob.

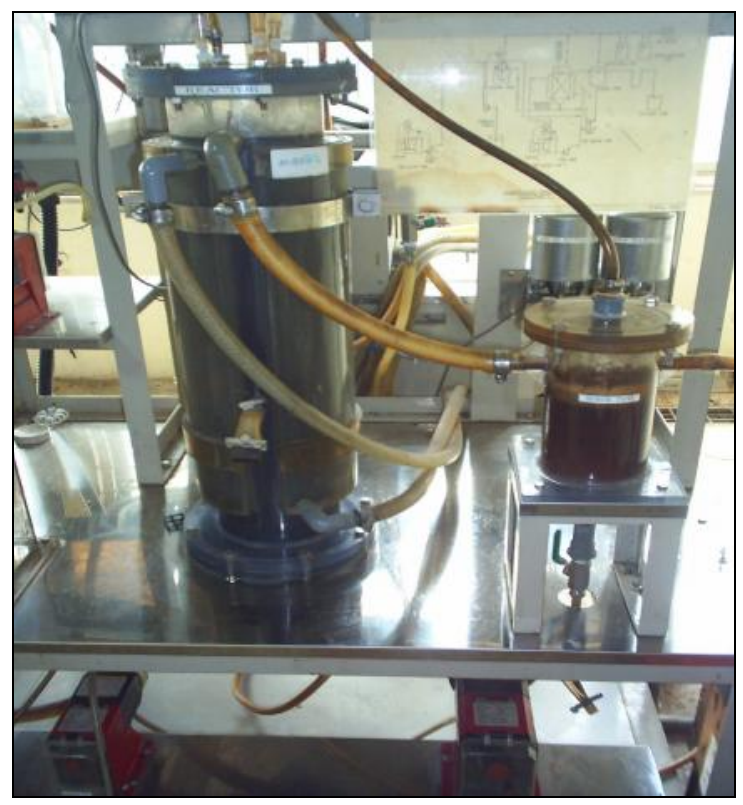

Gambar 3. Rangkaian Peralatan Penelitian Pengolahan Limbah Cair Percetakan Uang

\subsection{Proses Penelitian}

Pada awal penelitian, bioball dan 10 I lumpur mikroorganisme dimasukkan ke dalam bioreaktor anaerob. Mikroorganisme yang digunakan berasal dari bioreaktor anaerob RPH Cakung dan sebelum penelitian dilakukan, mikroorganisme ini telah digunakan untuk mengolah limbah cair pewarna rambut. Setelah itu dimasukkan influen limbah cair ke dalam bioreaktor.

Pengolahan limbah cair utas pada proses anaerob ini dilakukan secara draw and fill yaitu pengambilan sampel dari bioreaktor anaerob untuk analisa terlebih dahulu lalu pemasukkan limbah cair utas. Pada penelitian ini akan dicoba konsentrasi limbah cair utas yang berbeda-beda, yaitu $5 \%, 20 \%, 30 \%$, dan $40 \%$ limbah cair utas dalam limbah cair domestik. Setiap konsentrasi limbah cair utas dalam limbah cair domestik dilakukan pula variasi jumlah umpan atau influen mulai dari 0,25 I/hari, 0,50 I/hari, 0,75 I/hari, dan 1 I/hari secara draw and fill.

Limbah cair utas sebelum digunakan sebagai influen dilakukan penetralan. Pada awalnya dilakukan percobaan dengan konsentrasi limbah cair utas dan jumlah influen terendah, yaitu konsentrasi limbah cair utas $5 \%$ dengan jumlah influen 0,25 l/hari. Dalam percobaan ini, dilakukan analisa $\mathrm{COD}, \mathrm{pH}$, dan 
warna dari influen maupun efluen setiap harinya. Dengan analisa tersebut akan mendapatkan nilai efisiensi penurunan COD. Efisiensi penurunan COD ini merupakan parameter dalam keseharian penelitian untuk perubahan atau pergantian jumlah influen dan konsentrasi limbah cair utas. Pergantian jumlah influen dan konsentrasi limbah cair utas dilakukan apabila diperoleh tingkat efisiensi penurunan COD yang stabil. Rumus efisiensi penurunan COD yaitu :

\section{Efisiensi penurunan COD $(\%)=(a-b) \times 100 \%$}

keterangan $: \mathrm{a}=$ konsentrasi COD influen $(\mathrm{mg} / \mathrm{l})$ $\mathrm{b}=$ konsentrasi COD efluen $(\mathrm{mg} / \mathrm{l})$

Apabila sudah terlihat stabil, tetapi efisiensi penurunan COD masih dibawah 50\%, maka dilakukan penambahan jumlah influen menjadi $0,5 \mathrm{l} / \mathrm{hari}$ dengan konsentrasi limbah cair utas tetap 5\%. Selanjutnya dilihat efisiensi penurunan COD setiap hari sampai diperoleh kondisi stabil. Begitu pula dengan besarnya efisiensi penurunan COD dilihat apakah lebih rendah atau lebih tinggi dari sebelumnya.

Pada kondisi nilai efisiensi penurunan COD lebih rendah dari jumlah influen sebelumnya, maka dilakukan penurunan jumlah influen agar mikroorganisme tidak mengalami beban yang cukup tinggi untuk mendegradasi limbah cair dalam bioreaktor. Akan tetapi apabila kondisi nilai efisiensi penurunan COD lebih tinggi dari sebelumnya, maka dilakukan penambahan jumlah influen atau penambahan konsentrasi limbah cair utas.

Demikian seterusnya, dilakukan percobaan dengan memvariasikan konsentrasi limbah cair utas dan jumlah influen setiap hari sampai dicapai kondisi yang optimum. Kondisi optimum dicapai apabila efisiensi penurunan COD tinggi, waktu tinggal yang singkat dengan beban COD yang tinggi pula.

Konsentrasi limbah cair utas dalam limbah cair domestik dan jumlah influen berhubungan terhadap kinerja mikroorganisme dalam mendegradasi limbah cair. Nilai Waktu Tinggal Hidrolik (WTH) dan beban COD adalah diantaranya. WTH adalah waktu tinggal atau lamanya mikroorganisme mendegradasi limbah cair (influen) dalam suatu bioreaktor. Rumus dari WTH ini adalah :

WTH (hari) $\quad=\frac{\text { volume bioreaktor (I) }}{\text { jumlah influen (I/hari) }}$

Sedangkan beban COD adalah jumlah polutan yang masuk ke dalam suatu bioreaktor per satuan waktu, dinyatakan dalam g COD per liter volume reaktor per hari. Rumus beban COD adalah sebagai berikut:

\section{Beban COD (g/l.hari)}

Jmlh influen (l/hari) x konsentrasi COD (g/l) $=$

\section{Volume reaktor (I)}

\section{HASIL PENELITIAN}

\subsection{Hasil Analisa Komposisi Limbah Cair}

Tabel 2 menunjukkan hasil analisa laboratorium limbah cair utas yang diambil dari proses pencucian mesin cetak uang kertas. Nilai Total Suspended Solid (TSS) limbah cair utas ini sebesar $1.660 \mathrm{mg} / \mathrm{l}$, merupakan angka yang sangat tinggi melebihi baku mutu KEPMEN-51 tahun 1995 yaitu sebesar $400 \mathrm{mg} / \mathrm{l}$. Sedang untuk warna mempunyai nilai 1.341 PtCo yang dalam baku mutu parameter warna ini tidak ada ketentuannya. Untuk nilai $\mathrm{pH}, \mathrm{BOD}_{5}, \mathrm{COD}$, dan Metylen Blue Active Substance (MBAS) berturutturut yaitu 12, $18.960 \mathrm{mg} / \mathrm{l}, 64.200 \mathrm{mg} / \mathrm{l}$, dan $12,06 \mathrm{mg} / \mathrm{l}$ yang apabila dikaitkan dengan baku mutu KEPMEN-51 tahun1995 sebesar 6-9, 150 $\mathrm{mg} / \mathrm{l}, 300 \mathrm{mg} / \mathrm{l}$, dan $10 \mathrm{mg} / \mathrm{l}$, semuanya berada di atas baku mutu.

Tabel 2. Komposisi Limbah Cair Industri Percetakan Uang

\begin{tabular}{|l|l|c|c|}
\hline No. & Parameter & Satuan & Hasil \\
\hline A. & Fisika & & \\
\hline 1. & TSS & $\mathrm{mg} / \mathrm{l}$ & 1.600 \\
\hline 2. & $\mathrm{pH}$ & - & 12 \\
\hline 3. & Warna & PtCo & 1.341 \\
\hline B. & Kimia & & \\
\hline 1. & BOD5 & $\mathrm{mg} / \mathrm{l}$ & 18.960 \\
\hline 2. & COD & $\mathrm{mg} / \mathrm{l}$ & 64.200 \\
\hline 3. & MBAS & $\mathrm{mg} / \mathrm{l}$ & 12,06 \\
\hline 4. & Minyak \& Lemak & $\mathrm{mg} / \mathrm{l}$ & 0,6 \\
\hline
\end{tabular}

\subsection{Hasil Penelitian Konsentrasi COD}

Gambar 4 memperlihatkan hubungan perbedaan jumlah influen dan konsentrasi limbah cair utas dalam limbah cair domestik pada perubahan konsentrasi COD dan efisiensi penurunan COD. Berdasarkan gambar tersebut, dapat dilihat bahwa pada konsentrasi limbah cair utas $5 \%$ dalam limbah cair domestik dengan jumlah influen $0,25 \mathrm{l} /$ hari, $0,5 \mathrm{l} /$ hari, $1 \mathrm{l} / \mathrm{hari}$, dan $0,5 \mathrm{l} /$ hari pada waktu tinggal 40 hari, 20 hari, 10 hari, dan 20 hari menghasilkan efisiensi 
penurunan COD berturut-turut sebesar $37 \%$, $47 \%, 21 \%$ dan $34 \%$. Terlihat bahwa efisiensi penurunan COD pada konsentrasi limbah cair utas $5 \%$ dalam limbah cair domestik nilainya masih dibawah $50 \%$ untuk setiap variasi jumlah influen. Sedang untuk konsentrasi limbah cair utas $20 \%$ dalam limbah cair domestik dengan jumlah influen $0,25 \mathrm{l} /$ hari dan $0,50 \mathrm{l} /$ hari pada waktu tinggal 40 hari dan 20 hari diperoleh efisiensi penurunan COD sebesar $80 \%$ dan $51 \%$. Konsentrasi limbah cair utas 30\% dalam limbah cair domestik dengan jumlah influen 0,50 l/hari pada waktu tinggal 20 hari menghasilkan efisiensi penurunan COD sebesar $52,5 \%$. Percobaan terakhir yang dilakukan dengan konsentrasi limbah cair utas $40 \%$ dalam limbah cair domestik dengan jumlah influen 0,50 l/hari dan $0,75 \mathrm{l} /$ hari dengan waktu tinggal 20 hari dan 13 hari diperoleh efisiensi penurunan COD sebesar $50 \%$ dan $33 \%$. Pada konsentrasi limbah cair utas $40 \%$ dalam limbah cair domestik dengan jumlah influen $0,75 \mathrm{l} /$ hari menghasilkan nilai efisiensi penurunan COD semakin rendah pada hari-hari berikutnya.

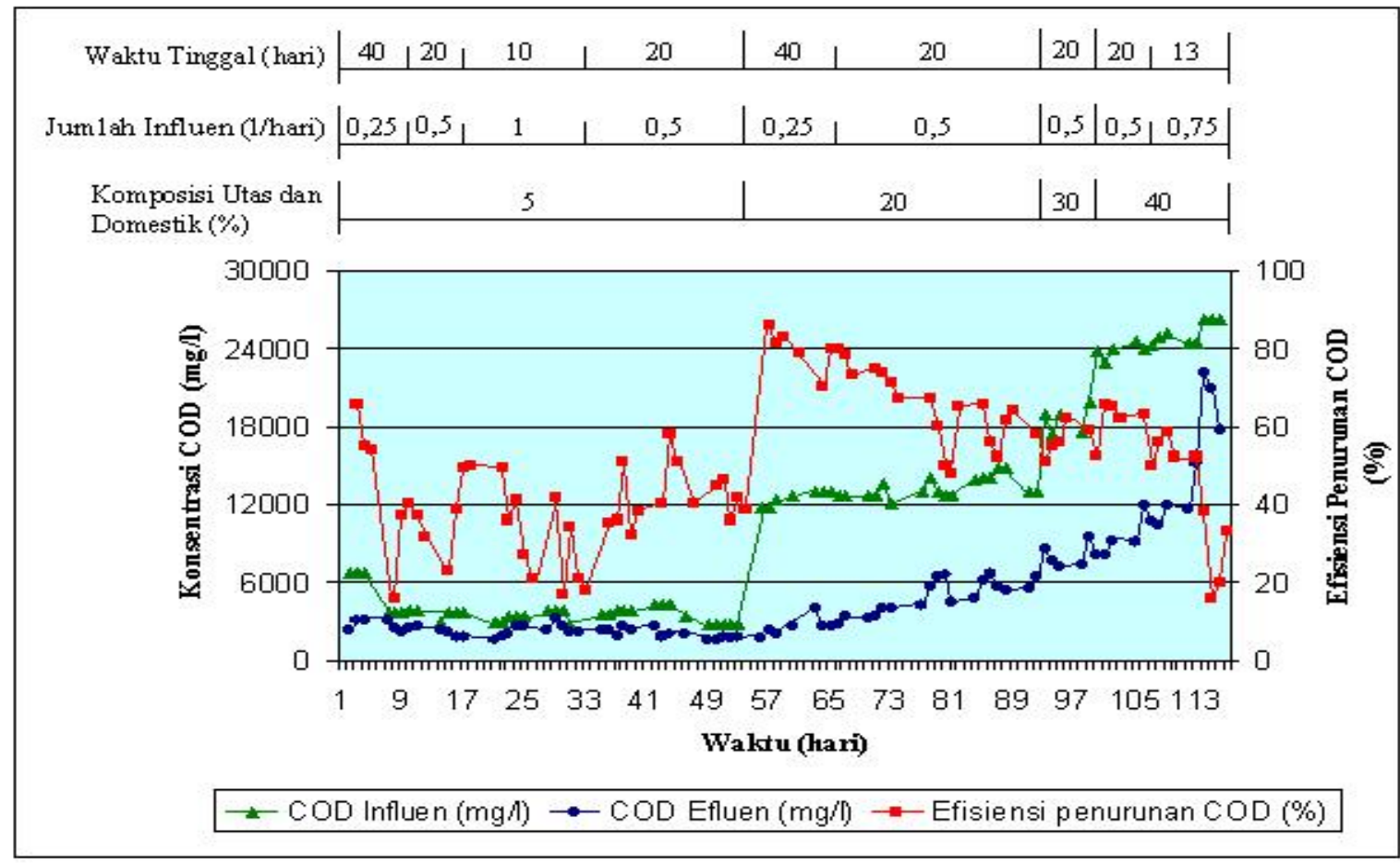

Gambar 4. Grafik Hubungan Perbedaan Jumlah Influen Dan Konsentrasi Limbah Cair Utas Pada Konsentrasi COD Dan Efisiensi Penurunan COD

Gambar 5 memperlihatkan hubungan perbedaan jumlah influen dan konsentrasi limbah cair utas pada efisiensi penurunan COD dan beban COD. Pada konsentrasi limbah cair utas $5 \%$ dalam limbah cair domestik dengan jumlah influen $0,25 \mathrm{l} /$ hari, 0,5 I/hari, $1 \mathrm{l} /$ hari, dan $0,5 \mathrm{l} /$ hari menghasilkan beban COD berturut-turut sebesar $0,09 \mathrm{~g} / \mathrm{l}$. hari, $0,18 \mathrm{~g} / \mathrm{l}$. hari, $0,35 \mathrm{~g} / \mathrm{l}$.hari, dan 0,18 $\mathrm{g} / \mathrm{l}$.hari. Sedang untuk konsentrasi limbah cair $20 \%$ dalam limbah cair domestik dengan jumlah influen $0,25 \mathrm{l} /$ hari dan $0,50 \mathrm{l} /$ hari menghasilkan beban COD sebesar 0,3 g/l.hari dan 0,6 g/l.hari. Konsentrasi limbah cair utas 30\% dalam limbah cair domestik dengan jumlah influen 0,50 l/hari memperoleh beban COD sebesar 0,95 g/l.hari. Percobaan terakhir pada konsentrasi limbah cair utas $40 \%$ dalam limbah cair domestik dengan jumlah influen $0,50 \mathrm{l} /$ hari dan $0,75 \mathrm{l} /$ hari diperoleh beban COD sebesar 1,2 g/l.hari dan 1,8 g/l.hari.
Berdasarkan Gambar 4, pada konsentrasi limbah cair utas $5 \%$ dalam limbah cair domestik, efisiensi penurunan COD terlihat masih di bawah $50 \%$ dikarenakan proses anaerob tidak cocok untuk mengolah limbah dengan konsentrasi polutan yang sangat rendah. Sedang untuk konsentrasi limbah cair utas $40 \%$ dalam limbah cair domestik dengan jumlah umpan 0,75 I/hari, menghasilkan konsentrasi COD efluen naik secara drastis sehari setelah penambahan. Naiknya konsentrasi COD menyebabkan efisiensi penurunan COD menjadi turun tajam. Disini dapat disimpulkan bahwa kondisi over load di dalam bioreaktor sudah tercapai sehingga tidak dapat diteruskan lagi proses degradasi limbah secara anaerob.

Apabila dilihat pada Gambar 5, maka didapatkan konsentrasi limbah cair utas yang optimum yaitu sebesar $30 \%$ dalam limbah cair domestik. Pada konsentrasi limbah cair utas 30\% 
dengan jumlah influen $0,5 \mathrm{I} /$ hari dan beban COD $0,95 \mathrm{~g} / \mathrm{l}$.hari menghasilkan efisiensi penurunan COD $52,5 \%$ serta memiliki waktu tinggal 20 hari. Kondisi yang optimum tersebut adalah kondisi dimana efisiensi penurunan COD tinggi pada waktu tinggal yang singkat dengan beban COD yang tinggi pula dan merupakan perpotongan antara garis efisiensi penurunan COD dan kenaikan beban COD.

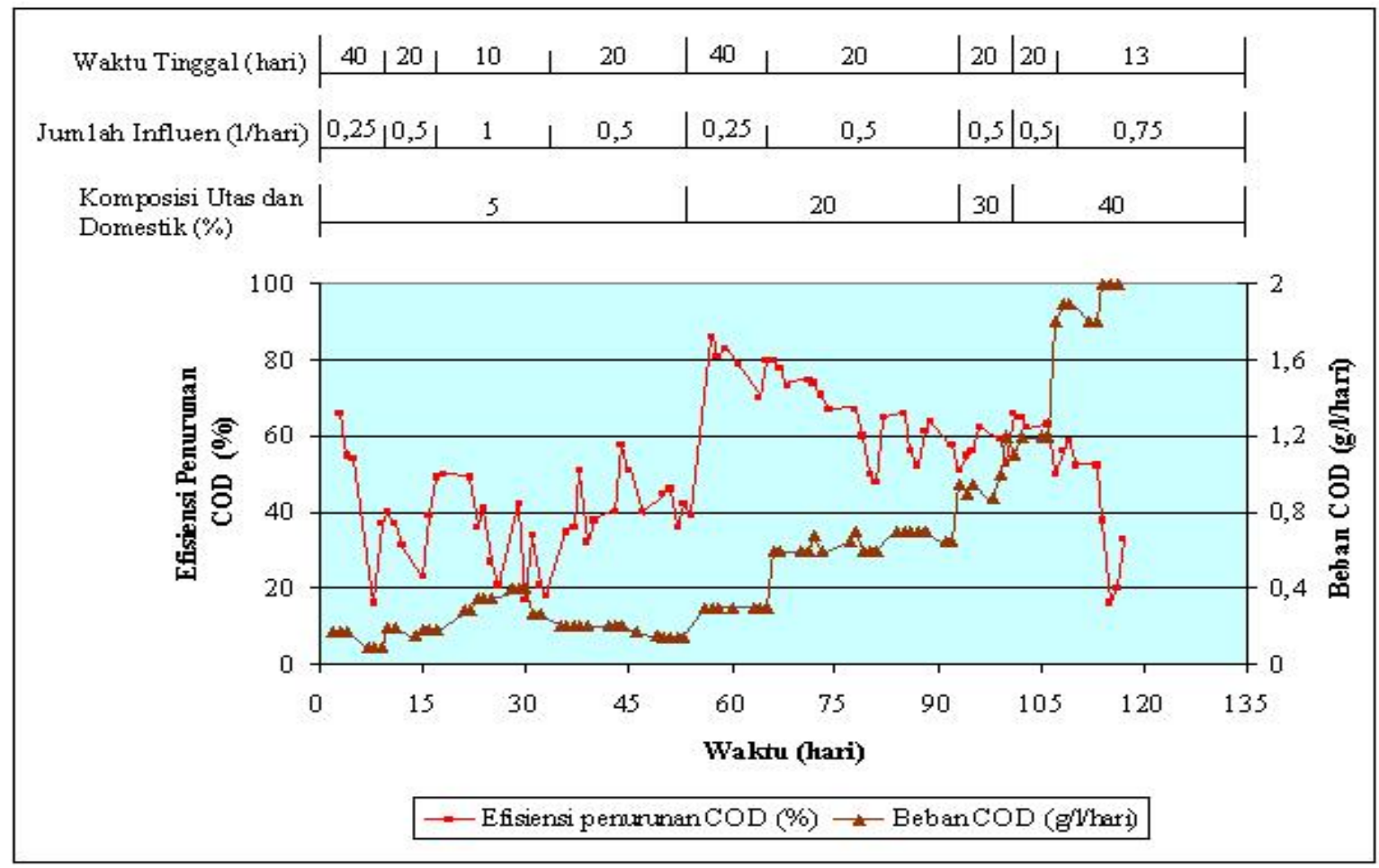

Gambar 5. Grafik Hubungan Perbedaan Jumlah Influen Dan Konsentrasi Limbah Cair Utas Pada Efisiensi Penurunan COD Dan Beban COD

Kondisi optimum ini nantinya akan dapat digunakan untuk merencanakan besarnya bioreaktor anaerob yang dapat diterapkan di Industri Percetakan Uang. Pada kondisi optimum dengan konsentrasi COD limbah cair yang masuk ke bioreaktor $19.900 \mathrm{mg} / \mathrm{l}$ dapat menghasilkan konsentrasi COD air hasil olahan $9450 \mathrm{mg} / \mathrm{l}$. Konsentrasi COD air olahan ini masih tergolong tinggi sehingga perlu proses lanjutan untuk dapat memenuhi baku mutu yang ditetapkan.

Pada proses anaerob ini memiliki waktu tinggal yang optimum selama 20 hari yang merupakan waktu tinggal cukup lama karena berdasarkan Tabel 3, pada umumnya kinerja proses anaerob dari berbagai jenis limbah cair kurang dari 20 hari (Eckenfelder, 1989).

\subsection{Hasil Penelitian Nilai pH}

Gambar 6 memperlihatkan hubungan perbedaan jumlah influen dan konsentrasi limbah cair utas pada perubahan nilai $\mathrm{pH}$. Berdasarkan gambar tersebut dapat dilihat bahwa pada hari ke 1 sampai dengan hari ke 43 , nilai $\mathrm{pH}$ influen bioreaktor berkisar 8-11. Kemudian kenaikan jumlah influen yang dilakukan secara bertahap dari $0,25 \mathrm{l} /$ hari sampai dengan $1 \mathrm{l} / \mathrm{hari}$ juga hampir tidak mempengaruhi $\mathrm{pH}$ dalam bioreaktor. Selama penelitian berlangsung, nilai $\mathrm{pH}$ efluen tetap netral dan stabil berkisar antara 7-8.

Dengan netralnya $\mathrm{pH}$ pada efluen, dapat disimpulkan bahwa jumlah influen, konsentrasi limbah cair utas dalam limbah cair domestik, dan waktu tinggal tidak berpengaruh terhadap perubahan nilai efluen $\mathrm{pH}$. Netralnya $\mathrm{pH}$ disebabkan oleh seimbangnya reaksi-reaksi yang terjadi pada proses anaerob, yaitu reaksi antara Acetogenesis dan Methanogenesis.

Pada proses Acetogenesis akan menghasilkan asam asetat, $\mathrm{H}_{2}$, dan $\mathrm{CO}_{2}$. Asam asetat ini di dalam air dapat menurunkan nilai $\mathrm{pH}$. Akan tetapi pada proses terakhir dalam pengolahan limbah cair secara anaerob, yaitu Methanogenesis, $\mathrm{CO}_{2}$ akan direaksikan dengan $\mathrm{H}_{2}$ oleh bakteri metan yang menghasilkan gas metan dan $\mathrm{H}_{2} \mathrm{O}$. Selain itu senyawa $\mathrm{NH}_{3}$ dari hasil penguraian senyawa organik pada proses anaerob akan bereaksi dengan $\mathrm{H}_{2} \mathrm{O}$ membentuk $\mathrm{NH}_{4} \mathrm{OH}$ yang dapat menaikkan nilai $\mathrm{pH}$, sehingga didapatkan $\mathrm{pH}$ limbah cair hasil olahan dari bioreaktor anaerob (efluen) stabil. 


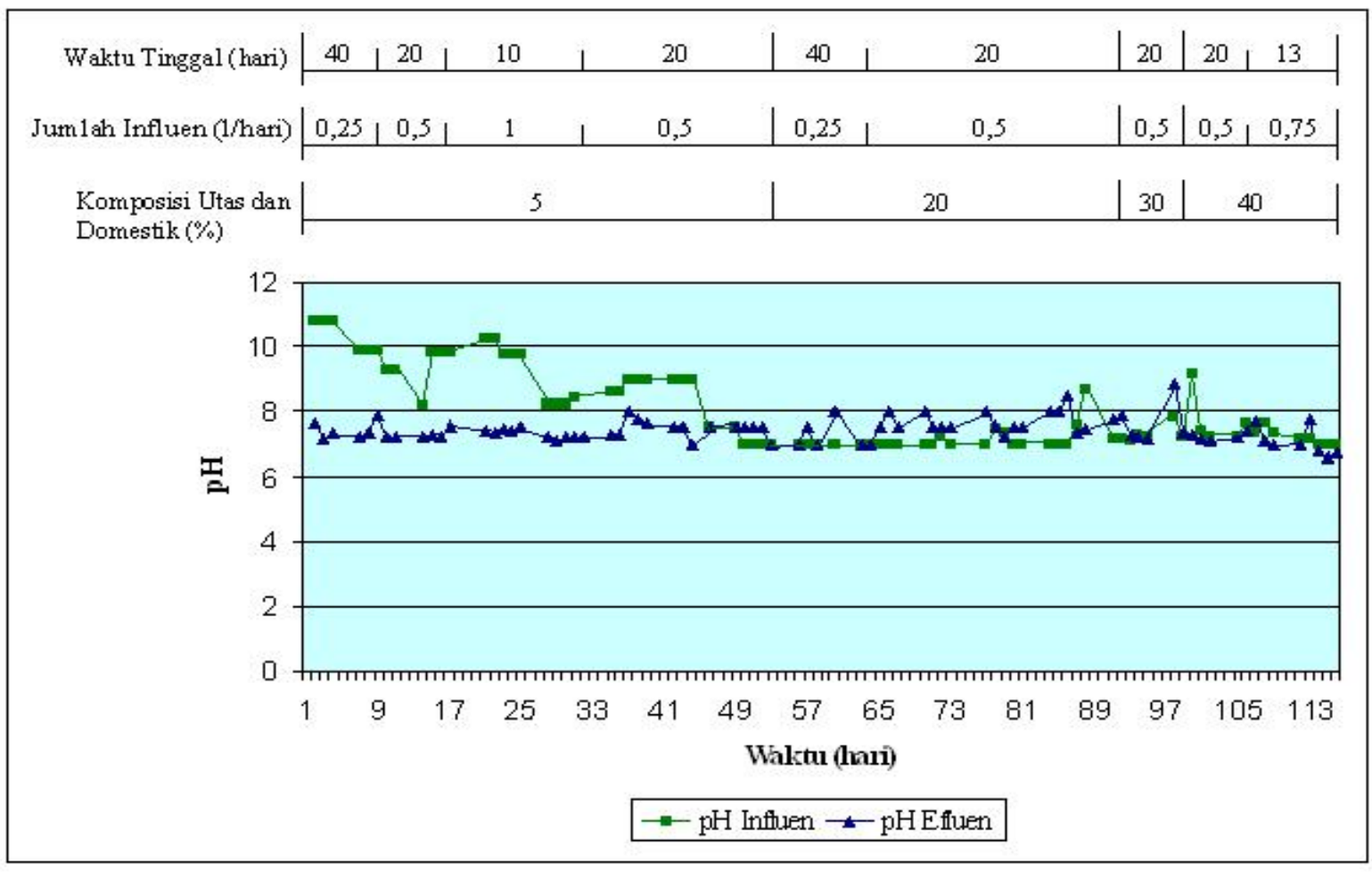

Gambar 6. Grafik Hubungan Perbedaan Jumlah Influen Dan Konsentrasi Limbah Cair Utas Pada Perubahan Nilai Ph

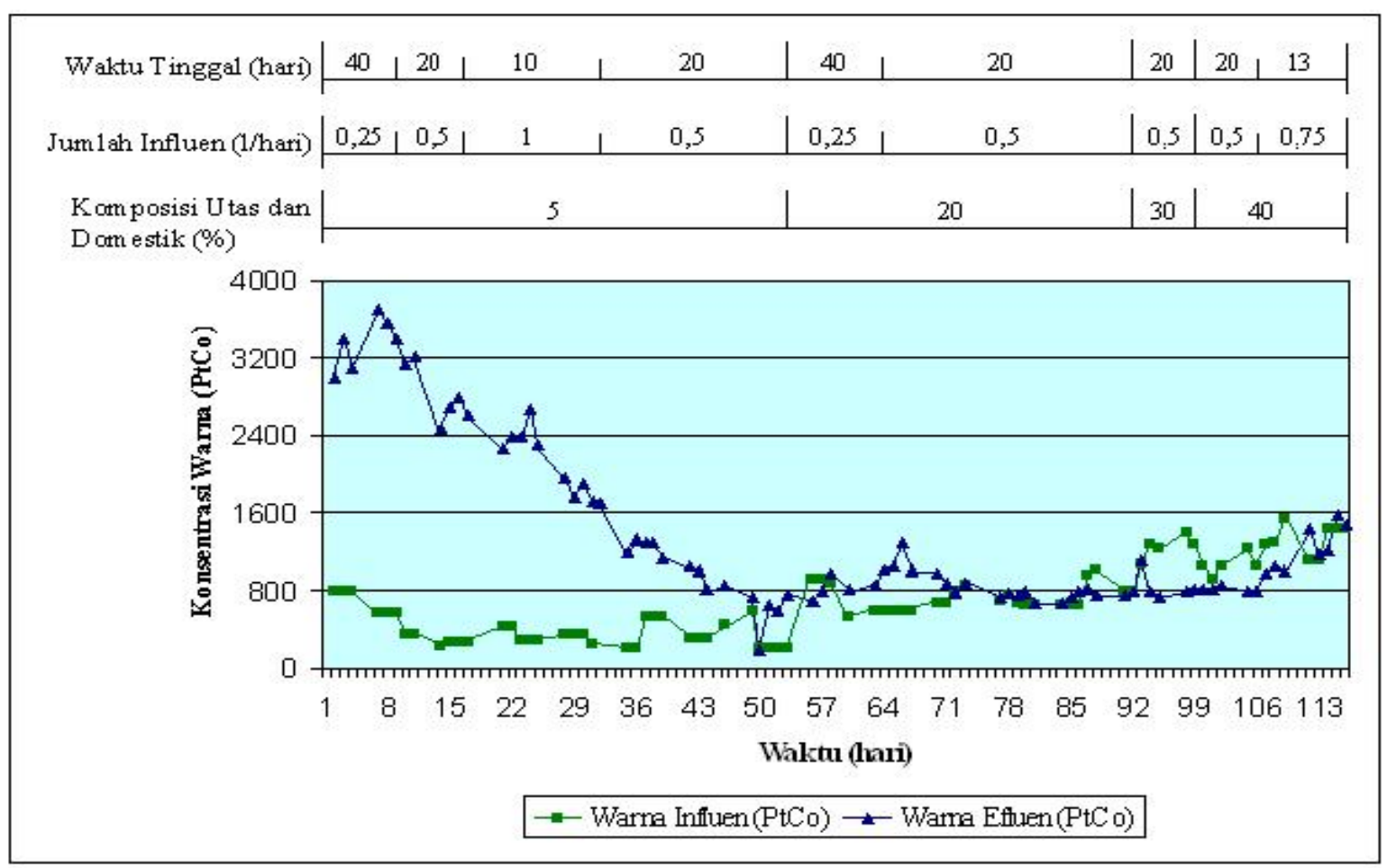

Gambar 7. Grafik Hubungan Perbedaan Jumlah Influen Dan Konsentrasi Limbah Cair Utas Pada Perubahan Nilai Konsentrasi Warna 


\subsection{Hasil Penelitian Konsentrasi Warna}

Gambar 7 memperlihatkan hubungan perbedaan jumlah influen dan konsentrasi limbah cair utas pada perubahan nilai konsentrasi warna yang diamati selama 115 hari. Seperti terlihat pada gambar tersebut, konsentrasi warna pada awal penelitian sangat tinggi yaitu pada hari pertama sampai dengan hari ke 42. Akan tetapi mulai hari ke 43 sampai dengan hari ke 91 konsentrasi warna influen dan efluen stabil dan kecenderungannya hampir sama yaitu sekitar 800 PtCo.

Pada pengamatan visual dan analisa warna untuk sampel-sampel hasil penelitian, konsentrasi influen limbah cair utas 5\% berwarna kuning dikarenakan kandungan limbah cair utasnya lebih sedikit dibanding dengan kandungan limbah cair domestik atau dapat dikatakan mengalami pengenceran. Pada konsentrasi limbah cair utas $20 \%$, efluennya berwarna coklat muda dibanding warna influen yang berwarna kuning tua kemungkinan dikarenakan mikroorganisme dapat mendegradasi limbah cair tersebut lebih sempurna.

Sedang untuk konsentrasi limbah cair utas $30 \%$, warna limbah cair efluen lebih jernih dibanding influen yaitu 1275 PtCo untuk konsentrasi influen dan 825 PtCo untuk konsentrasi efluen. Penurunan warna ini sebagai akibat terjadinya proses degradasi polutan atau senyawa organik menjadi senyawa yang lebih sederhana. Pada konsentrasi limbah cair utas $40 \%$, konsentrasi warna efluen lebih tinggi dibanding konsentrasi warna influen yaitu 1475 PtCo untuk efluen dan 1450 PtCo untuk enfluen. Kondisi ini kemungkinan disebabkan karena mikroorganisme yang berada di dalam bioreaktor anaerob tidak dapat mendegradasi limbah cair tersebut atau mikroorganisme mengalami over load.

Pada kondisi konsentrasi warna efluen lebih tinggi dari pada konsentrasi warna influen, kemungkinan dikarenakan unsur sulfida dalam limbah cair bereaksi dengan logam berat seperti besi (Fe) sehingga membentuk FeS. Senyawa FeS ini berwarna kehitaman sehingga mempengaruhi warna di dalam limbah cair. Menurut Svehla, G. (1979), reaksi sulfida dengan logam berat Fe dapat dilihat seperti di bawah ini :

$$
\mathrm{Fe}^{2+}+\mathrm{S}^{2-} \longrightarrow \mathrm{FeS}
$$

\section{KESIMPULAN}

Teknologi pengolahan limbah cair untuk industri percetakan uang (utas) dapat dilakukan dengan menggunakan Anaerobic Fixed Bed Reactor Dalam penelitian proses pengolahannya, limbah cair utas ini dicampur dengan limbah cair domestik. Dari data penelitian yang telah dilakukan diperoleh kesimpulan sebagai berikut:

1. Anaerobic Fixed Bed Reactor dapat mendegradasi polutan organik yang ada dalam limbah cair utas. Kondisi yang optimum pada prosesnya yaitu dengan perbandingan konsentrasi limbah cair utas $30 \%$ dalam limbah cair domestik, jumlah umpan 0,5 I/hari, beban COD 0,95 g/l.hari, dan waktu tinggal 20 hari. Pada kondisi optimum ini efisiensi penurunan COD yang dapat dicapai adalah sebesar $52,5 \%$, yaitu COD dapat turun dari $19.900 \mathrm{mg} / \mathrm{l}$ menjadi $9.450 \mathrm{mg} / \mathrm{l}$.

2. Nilai $\mathrm{pH}$ efluen dari bioreaktor anaerob berkisar 7-8 dan sudah memenuhi baku mutu. Sedangkan konsentrasi warna efluen masih pada angka 825 Pt.Co.

\section{B. Saran}

Limbah cair utas hasil pengolahan dari efluen bioreaktor anaerob konsentrasi polutannya dalam hal ini konsentrasi COD masih tinggi sehingga perlu diolah lebih lanjut dengan proses biologis aerob sebelum dibuang ke perairan.

Adapun teknologi proses aerob yang dapat diterapkan untuk pengolahan lanjutan efluen bioreaktor anaerob diantaranya adalah sistem lumpur aktif, sistem Rotating Bio Contactor atau sistem lagoon. Dan ini perlu dilakukan penelitian lebih lanjut.

\section{DAFTAR PUSTAKA}

1. Alaerts, G. A. dan S. S. Santika. 1984. Metoda Penelitian Air. Usaha Nasional. Surabaya.

2. Eckenfelder, W. Wesley. 1989. Industrial Water Pollution Control. Mc Graw-Hill, Inc. Singapura.

3. Gintings, P. 1992. Mencegah dan Mengendalikan Pencemaran Industri. Pustaka Sinar Harapan. Jakarta.

4. Ikbal, 2006. Teknologi Pengolahan Limbah Sistem Anaerobik dan Pemanfaatan Biogas Sebagai Sumber Energi. PTL-BPPT. Jakarta.

5. Japanese Industrial Standards Committee (JIS). 1989. Testing Methods for Industrial Wastewater. Japanese Standards Association. Tokyo.

6. Mahida, U. N. 1984. Pencemaran Air dan Pemanfaatan Limbah Industri. Terjemahan G. A. Ticoalu. CV Rajawali. Jakarta.

7. Metcalf and Eddy. 1991. Wastewater Engineering : Treatment, Disposal, and Reuse. $3^{\text {rd }}$ edition. Mc Graw-Hill, Inc. USA. 
8. Metcalf and Eddy. 2003. Wastewater Engeneering : Treatment and Reuse. $4^{\text {th }}$ edition. Mc Graw-Hill, Inc. USA.

9. Nugroho, R. 2005. Proses Pengolahan Limbah Cair dengan Sistem Lumpur Aktif. PTL-BPPT. Jakarta.

10. Nugroho, R. 2006. Pemilihan Teknologi yang Tepat untuk Pengolahan Air Limbah Domestik di Perkotaan. PTL-BPPT. Jakarta.
11. Scragg, A. H. 1991. Bioreactors in Biotechnology : A Practical Approach. Ellise Horwood Limited. England.

12. Sugiharto. 1987. Dasar-dasar Pengelolaan Air Limbah. Ul-Press. Jakarta.

13. Svehla, G. 1979. Vogel : Buku Teks Analisis Anorganik Kualitatif Makro dan Semimikro. Bagian I. Longman Group Limited. London.

\section{LAMPIRAN}

Tabel 1. Karakteristik Limbah Cair Domestik

\begin{tabular}{|c|c|c|c|c|}
\hline \multirow[t]{2}{*}{ Kontaminan } & \multirow[t]{2}{*}{ Satuan } & \multicolumn{3}{|c|}{ Kelas dan Konsentrasi } \\
\hline & & Lemah & Sedang & Kuat \\
\hline Total Solid (TS) & $\mathrm{mg} / \mathrm{l}$ & 350 & 700 & 1200 \\
\hline - Terlarut, Total (TDS) & $\mathrm{mg} / \mathrm{l}$ & 250 & 500 & 850 \\
\hline$=$ Tetap & $\mathrm{mg} / \mathrm{l}$ & 195 & 300 & 525 \\
\hline$=$ Volatil & $\mathrm{mg} / \mathrm{l}$ & 105 & 200 & 325 \\
\hline - Padatan Suspensi (SS) & $\mathrm{mg} / \mathrm{l}$ & 100 & 200 & 350 \\
\hline$=$ Tetap & $\mathrm{mg} / \mathrm{l}$ & 30 & 50 & 75 \\
\hline$=$ Volatil & $\mathrm{mg} / \mathrm{l}$ & 70 & 150 & 275 \\
\hline Padatan Terendapkan & $\mathrm{mg} / \mathrm{l}$ & 5 & 10 & 20 \\
\hline $\mathrm{BOD}_{5}, 20^{\circ} \mathrm{C}$ & $\mathrm{mg} / \mathrm{l}$ & 100 & 200 & 300 \\
\hline TOC & $\mathrm{mg} / \mathrm{l}$ & 100 & 200 & 300 \\
\hline COD & $\mathrm{mg} / \mathrm{l}$ & 250 & 500 & 1000 \\
\hline Nitrogen (Total sbg N) & $\mathrm{mg} / \mathrm{l}$ & 20 & 40 & 85 \\
\hline - Organik & $\mathrm{mg} / \mathrm{l}$ & 8 & 15 & 35 \\
\hline - Ammonia Bebas & $\mathrm{mg} / \mathrm{l}$ & 12 & 25 & 30 \\
\hline - Nitrit & $\mathrm{mg} / \mathrm{l}$ & 0 & 0 & 0 \\
\hline - Nitrat & $\mathrm{mg} / \mathrm{l}$ & 0 & 0 & 0 \\
\hline Pospor (Total sbg P) & $\mathrm{mg} / \mathrm{l}$ & 6 & 10 & 20 \\
\hline - Organik & $\mathrm{mg} / \mathrm{l}$ & 3 & 3 & 5 \\
\hline - Anorganik & $\mathrm{mg} / \mathrm{l}$ & 4 & 7 & 15 \\
\hline Klorida & $\mathrm{mg} / \mathrm{l}$ & 20 & 50 & 100 \\
\hline Sulfat & $\mathrm{mg} / \mathrm{l}$ & 20 & 30 & 50 \\
\hline Alkalinitas $\left(\mathrm{sbg} \mathrm{CaCO}_{3}\right)$ & $\mathrm{mg} / \mathrm{l}$ & 50 & 100 & 200 \\
\hline Lemak (Grease) & $\mathrm{mg} / \mathrm{l}$ & 50 & 100 & 150 \\
\hline Total coliform & $\mathrm{nol} / 100 \mathrm{ml}$ & $10^{6}-10^{7}$ & $10^{7}-10^{8}$ & $10^{7}-10^{9}$ \\
\hline VOC & $\mu \mathrm{g} / \mathrm{l}$ & $<100$ & $100-400$ & $>400$ \\
\hline
\end{tabular}


Tabel 3. Kinerja Proses Pengolahan Anaerob Dari Berbagai Jenis Limbah

\begin{tabular}{|c|c|c|c|c|c|}
\hline Wastewater & Proses & $\begin{array}{c}\text { Beban } \\
\mathrm{kg} /\left(\mathrm{m}^{3} \text {.hari) }\right.\end{array}$ & $\begin{array}{l}\text { WTH } \\
\text { (hari) }\end{array}$ & $\begin{array}{l}\text { Suhu } \\
\left({ }^{\circ} \mathrm{C}\right)\end{array}$ & $\begin{array}{c}\text { Removal } \\
\text { (\%) }\end{array}$ \\
\hline Meat packing & Anaerob & 3,2 (BOD) & 12 & 30 & 95 \\
\hline Meat packing & contact & 2,5 (BOD) & 13,3 & 35 & 95 \\
\hline Keiring & & 0,085 (BOD) & 62,4 & 30 & 59 \\
\hline Slaughter house & & 3,5 (BOD) & 12,7 & 35 & 95,7 \\
\hline Citurs & & 3,4 (BOD) & 32 & 34 & 87 \\
\hline Synthetic & Upflow & 1,0 (COD) & - & 25 & 90 \\
\hline Pharmaceutical & filter & 3,5 (COD) & 48 & 35 & 98 \\
\hline Pharmaceutical & & $0,56(\mathrm{COD})$ & 36 & 35 & 80 \\
\hline Gaur gum & & 7,4 (COD) & 24 & 37 & 60 \\
\hline Rendering & & 2,0 (COD) & 36 & 35 & 70 \\
\hline Landfill leachate & & 7,0 (COD) & - & 25 & 89 \\
\hline Paper-mill foul & & $10-15$ (COD) & 24 & 35 & 77 \\
\hline \multicolumn{6}{|l|}{ Condensate } \\
\hline Synthetic & & 0,8-4,0 (COD) & $0,33-6$ & $10-3$ & 80 \\
\hline Paper-mill foul & Expanded & $35-48$ (COD) & 8,4 & 35 & 88 \\
\hline Condensate & bed & & & & \\
\hline Skimmed milk & & 71 (COD) & 5,3 & 30 & 90 \\
\hline Sauerkraut & USAB & 8-9 (COD) & - & - & 90 \\
\hline Potato & & $25-45$ (COD) & 4 & 35 & 93 \\
\hline Sugar & & 22,5 (COD) & 6 & 30 & 94 \\
\hline Champagne & & 15 (COD) & 6,8 & 30 & 91 \\
\hline Sugar beet & & 10 (COD) & 4 & 35 & 80 \\
\hline Brewery & & 95 (COD) & - & - & 83 \\
\hline Potato & & 10 (COD) & - & - & 90 \\
\hline Paper-mill foul & & 4-5 (COD) & 70 & 35 & 87 \\
\hline \multicolumn{6}{|l|}{ Condensate } \\
\hline Potato & & 0,2 (COD) & 360 & 25 & 90 \\
\hline Corn starch & ADI-BFV & 0,45 (COD) & 168 & 35 & 85 \\
\hline Dairy & & 0,32 (COD) & 240 & 30 & 85 \\
\hline Confectionary & & $0,51(\mathrm{COD})$ & 336 & 37 & 85 \\
\hline
\end{tabular}

